\title{
Scopes of Solidarity in Times of Crisis: Insights from Poland
}

\author{
Janina Petelczyc, Rafał Bakalarczyk, \\ and Ryszard Szarfenberg
}

\section{Introduction}

Civil society organisations in Poland have stepped up their activities in order to address social problems and meet the needs of deprived groups over the last decade. Even though organisations working in different issue fields (migration, unemployment and disabilities) have had different priorities and agendas, the expansion of solidarity actions has been a general

Results presented in this chapter have been obtained within the project "European paths to transnational solidarity at times of crisis: Conditions, forms, role models and policy responses" (TransSOL). This project has received funding from the European Union's Horizon 2020 research and innovation programme under grant agreement No 649435.

J. Petelczyc $(\bowtie)$

Department of Social Insurance, SGH Warsaw School of Economics, Warsaw, Poland

e-mail: jpetel@sgh.waw.pl

R. Bakalarczyk

Independent Researcher, Warsaw, Poland e-mail: raf_19@tlen.pl 
development across the three domains. This raises questions about the societal factors driving the development of civic solidarity initiatives and practices. The Polish experience seems particularly instructive because civil society organisations have been operating within a societal environment that has been less affected by the various crises of the European Union (EU), as compared to other countries such as Greece or Italy. Still, Poland has experienced significant socio-economic and political changes, to which civil society organisations have reacted. The comparison of the three issue fields allows us to highlight the specificities and similarities of this development. In particular, it will show that civic solidarity was driven more strongly by public policy responses than by those moments of crises, which government actions were intended to address.

Poland was not directly affected by the economic and financial crises of 2009, nor by the massive inflow of refugees in the years 2015 and 2016, although the indirect effects have been considerable. On the one hand, the country seems to have coped relatively well with the worldwide economic crisis and was the only EU Member State with a continuous positive gross domestic product (GDP) growth. Compared to the EU, the average level of GDP change in Poland was relatively moderate, even in 2009. In fact, among European countries, only Polish GDP growth was not directly affected by the economic crisis. However, in spite of good economic conditions during times of hardship in Europe, the Polish government used the crisis as an excuse for continuing liberal policy changes that had been initiated beforehand, partly in order to comply with the Procedure of Excessive Deficit imposed by the EU. On the other hand, social and labour indicators were not as positive as economic ones, but these were neglected by the Polish government. As a result, the (partly hidden) economic crisis and weak policy responses of the state to this phenomenon were reflected in citizens bearing the brunt of it (Theiss et al. 2017). Its impact on the labour market was significant. Unemployment, especially youth unemployment, rose, and growing

R. Szarfenberg

Faculty of Political Science and International Studies, University of Warsaw,

Warsaw, Poland

e-mail: r.szarfenberg@uw.edu.pl 
numbers of people were forced to work on "civil contracts", deprived of labour and social security rights. "Anti-crisis" packages introduced by the government protected employers rather than employees. The government also introduced austerity measures such as cuts in funding for public employment services, including unemployment benefits, as well as freezing salaries of some groups of workers in the public sector (Petelczyc 2017).

Austerity policies, however, did not only affect workers and the unemployed, but they also affected other groups, like the disabled. In Poland, 4.7 million people live with disabilities, among whom 3.1 million have formally been classified as disabled. In the group of disabled adults, $22.7 \%$ have the status of a person with advanced disability (Ministry of Family, Labour and Social Policy 2017). Many of them demand longterm care and support in activities of daily living. In the Polish context, this kind of care is provided in large part by the family and the informal sector. The well-being of those people and their families depends partly on social benefits. Access to those benefits became limited for the caregivers of the disabled adults in 2013. As a reaction to the changes in law, several social initiatives rallied around the caregivers and initiated protest movements.

On the other hand, the so-called refugee crisis has also had repercussions on public debate in Poland. Even though the inflow of migrants from Ukraine was substantial, contributing thus to a migrant community of about 2 million people, public concerns were particularly sensitive towards refugees fleeing from wars, persecution and poverty outside Europe. Against the EU's attempts to establish a system of burden-sharing and relocation of refugees, the Polish government resisted. Poland stands out as the country that took in the lowest number of refugees: 3500 nonEU asylum applicants in 2015 and 2500 in 2016, compared to 249,000 in 2015 and 631,000 in 2016 in Germany (Eurostat 2017). Three hundred and forty-eight refugees were granted permission to stay in 2016, whereas in 2017, 150 got official permission to stay (Urząd do Spraw Cudzoziemców 2018). The so-called refugee crisis did not directly impact on Polish society, given that Poland was not part of the transit routes of refugees, but it did affect public policies indirectly, because the inflow of refugees coincided with the terrorist attacks of 2015 and a political 
campaign preceding the Polish parliamentary election in October 2015, which contributed to the politicisation of the issue.

In this chapter, we wish to highlight the experiences of transnational solidarity organisations (TSOs) working in the field of unemployment, migration and disability analysed in the context of the TransSOL crossnational project (see TransSOL 2016). In particular, we aim to highlight the way in which these organisations have adapted to the socio-economic and political developments, and the challenges they have presented to Polish society. We aim to answer the following questions: Are there significant changes in how TSOs operate and respond to societal needs and grievances? To what extent are these changes a reaction to the socioeconomic and political developments? And how (if at all) have the crises affected the TSOs' understanding of solidarity in the different fields of unemployment, migration and disability?

This chapter is based on the qualitative analysis of 30 interviews with the representatives of solidarity organisations working in the field of unemployment (labour), migration and disabilities. In order to grasp the experiences of TSOs in a comprehensive manner, we followed a sampling strategy that strived to increase diversity, for example, in terms of issue fields, action repertoires and organisational features. We conducted interviews with 21 charity help-/service-oriented organisations (7 working in the field of migration, 9 in unemployment and 5 in disability) and 17 protest/social movement/policy-oriented organisations (5 working in the field of migrations, 7 in unemployment and 5 in disability). Most of the organisations deliberately employ a hybrid approach in their actions, combining the provision of various services with an engagement in policy-making on local, national and/or international level/s. Given that research was interested in cross-national linkages and references, only organisations and groups were included in the sampling that exhibited a transnational element (for instance, beneficiaries, supporters, partners, sponsors or missions). Interviews were conducted between September and November 2016. ${ }^{1}$

\footnotetext{
${ }^{1}$ For more information on sampling, see the introduction to this volume and https://blogs.unisiegen.de/transsol/files/2016/12/Integrated-Report-on-Reflective-Forms-of-TransnationalSolidarity.pdf
} 


\section{Organisations in Times of Crisis: Theoretical Framework}

Civil society organisations are engaged in acts of solidarity in support of deprived target groups. For Rymsza (2006), solidarity is composed of two forms of social ties. On the one hand, solidarity is based on social ties and a mutual concern for the common good. On the other hand, solidarity is based on institutionalised ties (expressed in public authorities' activities) and non-institutionalised ties (mediated by non-governmental organisations engaged in social and political support for deprived groups). According to this framework, social policies and public measures of a redistributive nature are a manifestation of institutionalised (state) solidarity, while charitable activities and political advocacy by TSOs are an expression of non-institutionalised (civic) solidarity. Rymsza's theory of solidarity can be complemented by another dimension: the scope of solidarity. Public or social solidarity could be related to a very narrow issue and group of people (such as people deprived of some cash benefit after the reform of social welfare system) or to a very broad array of issues and many different groups (namely all people with disabilities and people in poverty and all issues which are important to them). In addition, the scope of solidarity in terms of involved groups and issues may be national or international.

This concept of solidarity highlights that organised forms of solidarity, which are central to this chapter, are strongly embedded in the socioeconomic and political structure of their environment. In fact, we might expect that the socio-economic situation and the levels of institutionalised (state) solidarity might impinge on the scope and intensity of activities by TSOs. In particular, we should expect that the financial and economic crisis would have impacted on civic solidarity in Poland. The mechanism could be formulated in causal terms: The crisis causes an increase in social needs (more people in unemployment and in poverty, etc.) and a reduction in the ability of the state to satisfy them by means of public funds (lower budget revenues). Public and non-public solidarity activities supported by the state budget may suffer substantial losses, thus increasing a gap between growing social needs (increase in demand for 
solidarity) and responses of the public sector (decrease in supply of solidarity). Citizens and existing civil society organisations might be called on to fill this gap by providing activities of non-state social entities of solidarity (TSOs).

This general assumption, however, needs to be differentiated into two propositions, given that scholarly writing has been sceptical about the explanatory power of objective deprivations. In fact, the assumption that TSOs respond to rising social needs in times of crisis presupposes that civic solidarity is a pure mirror of socio-economic grievances. Studies of social movement and civil societies have shown, however, that these responses are mediated by two factors: the availability of organisations and organised forms of action and the availability of political opportunities and targets (Giugni and Grasso 2016; Grasso et al. 2019).

On the one hand, we know that collective action is dependent on existing organisational fields that more often than not adapt to or expand the range of their activities in order to meet (new) needs. Labour organisations, for instance, play an important role. They are rather old social actors that have learned to adapt to new social realities, including dynamically changing cultural patterns that increasingly shape the working environment (Milner and Mathers 2013). According to Diani, unions, which have been in crisis for years, remain significant social actors by renewing themselves and introducing diverse strategies (Diani 2019). One part of the labour organisations' strategy to cope with this challenge includes taking actions in favour of groups or issues which are not traditionally understood as labour rights, like supporting atypical workers (Gumbrell-McCormick 2011), women and ethnic minority members (Kirton and Greene 2005) or victims of domestic violence (Wibberley et al. 2018). One can also see a significant change in the organisations active in the field of labour in the context of increasing migration caused by both the typical free movements of persons and the refugee influx. The experience of European countries proves the existence of a developed catalogue of activities that offer support to foreigners by labour civil society organisations. The same situation can be seen with regard to unions, whose tradition proves that they played an important role as a political and social actor in the fight for the rights of migrants (Marino et al. 2015). 
On the other hand, political opportunities and targets are a decisive factor in arousing organised activities of solidarity. TSOs require civic liberties to organise and mobilise support publicly, and they require some sort of political and public support (for instance, in terms of funding) in order to provide services and maintain their activities. Moreover, TSOs are clearly involved in ongoing policy debates and related political conflicts, because they advocate for social rights and entitlements in order to institutionalise their call for solidarity. This implies that TSOs will step up their activities when the state fails to provide liberties, financial support or social rights. The mobilisation of solidarity during the last decade might thus not be a direct reaction to the economic and financial crisis, but rather to the changed public agenda of the state. In this regard, we can assume that the effects of the crisis have been indirect. The economic crisis might have aroused solidarity activities due to the changed government policy of austerity in general (which are at least partly shaped by the excessive deficit procedure imposed on Poland by the EU), and regulatory and benefits cuts reducing social security protection and social investment, in particular. Organised forms of solidarity seem to be motivated by government actions.

The centrality of austerity policies as causes and targets of political protests and solidarity actions has been confirmed by previous studies (della Porta 2015; Ancelovici et al. 2016). Civil society organisations help people who have not enough resources (both financial and social capital) and whose needs are ignored or insufficiently addressed, for example, by the state (Mohan 2002). For the Greek example, Chrysostomou (2015) showed that when the state fails and acts insufficiently, it opens the door to the rise of civil society organisations. In this sense, policies of austerity might encourage civil society organisations and civil society activists to enhance and expand solidarity initiatives and practices. In these terms, the crisis and its policy responses have become a catalyst for the empowerment of civil society in Greece (Sotiropoulos and Bourikos 2014). However, this situation is also true for Poland, given that rising unemployment rates have run parallel to a growing budget deficit and public debt, leading to increased pressures upon the government to reduce its spending. Therefore, the country has also implemented several cuts in public spending, justified by the crisis (Rae 2012; Theiss et al. 2017). It 
is to be expected that the introduction of austerity policies had led to an increase and/or expansion of organised solidarity by existing and/or new TSOs, both formal and informal (Cabot 2018; Chrysostomou 2015). Informal social networks, self-help groups and more formal civil society organisations seem to rise in answer to insufficient state activity by providing social services and political advocacy for those target groups with severe needs and disadvantages (Sotiropoulos and Bourikos 2014).

\section{The Perception of TSOs' Context Conditions}

Previous research has shown that civil society organisations adapt their organisational work to upcoming grievances and restrictive policies and often also to the impact of international crises. However, in the Polish case, these adaptations seem to be driven only marginally by the various crises affecting the EU itself. Much more important is the way that TSOs perceive the societal conditions and transformations and the political opportunities and constraints. In this regard, our interviews reveal that perceptions diverge considerably in all three fields. While some TSOs acknowledge objective grievances caused by the socio-economic crisis of the EU, the wars in the Middle East and the so-called refugee crisis as shaping factors, most of them put rather long-lasting conflicts and problems and inadequate policy-reactions centre stage. A number of the interviewed TSOs share the view that the economic and financial crisis had some direct and/or indirect influence on their work. Those who address the economic crisis underline, for instance, that the crisis forced the organisation to quit certain activities. Others mention that, while in times of economic stability, the organisation was based on the financial contributions of their members, during the economic recession, their members had less money to give to the organisation, which made effective activity more difficult. Moreover, other interviewees point out that in times of economic crisis and job scarcity, labour migration might have been perceived as a risk for workers in some segments of the labour market and, consequently, led to a weakening of solidarity towards immigrants.

In comparison, other interviewees declare no, little or only indirect influence of it on their organisation's activity and on the perceived level 
of solidarity towards the groups they care about. For some of the TSOs in the field of migration, more long-lasting international developments or external factors, such as the conflict in Syria or the difficult situation in Ukraine, are more influential on their work than the economic crisis. While the influx of many Ukrainian migrants affects the work of Polish TSOs more directly at home, the repercussions of the so-called refugee crisis are more consequential for those TSOs operating in countries of war and conflict outside Europe. These organisations are less concerned with developments in national policy-making because their activities target problems outside Polish territory and the direct responsibility of the Polish state.

Another reason for the limited (perceived) impact of the economic crisis on the situation of certain organisations is the fact that many of them do not base their work on huge financial resources and are oriented on non-material rather than material support provision. In fact, several TSOs declare that their main activity is supporting the rights of certain groups, advisory and moral support, but not necessarily financial or material resource distribution. Others emphasise that the solidarity (or lack of it) with migrants or refugees is not an issue of the economy and/ or resources, but rather of how people think and act, what they are conscious of and how the problems are discussed. Here, it should be added that the Polish debate on refugees was extremely politicised in the context of pre-election campaigns and anti-migration mobilisation by the oppositional right-wing party. $^{2}$ Moreover, many problems the interviewed

\footnotetext{
${ }^{2}$ The refugee crisis in Europe occurred simultaneously with a political campaign preceding the Polish parliamentary election in October 2015. In July 2015, the Polish government declared its readiness to welcome 2000 refugees into Poland. This was, however, highly criticised by the opposition. In September 2015 Jarosław Kaczyński (Law and Justice party leader, in opposition) claimed in Parliament that " under foreign pressure and without the consent of the Polish people, the government does not have the right to take decisions which are highly probable to negatively affect our life $(. .$.$) the number of foreigners will increase and then they will stop respecting our laws and$ customs (...) would you like us to quit being hosts in our country?' He also proposed what he called ordo caritatis - an order of compassion which means: First the closest ones, then the nation and then the others" (Narkiewicz 2017). The significance of this term-first the closest ones, and so forth-reveals an attempt to establish a kind of "natural hierarchy" of solidarity relations (Szczupak et al. 2018). Kaczyński's claims went further in October 2015 when he said that "migrants have already brought diseases like cholera and dysentery to Europe, as well as all sorts of parasites and protozoa, which (...) while not dangerous in the organisms of these people, could be dangerous here" (Politico 2017). After Law and Justice's victory in the parliamentary election in
} 
migration TSOs have to cope with are rather related to the difficulties of economic and social integration of migrants and refugees in Poland and to the formal barriers on the foreigners' lives and work in Poland. Some of the issues they have to tackle, for instance, with regard to accommodation, are to some extent caused by the insufficient policy of the state, public authorities and institutions. Thus, the ways in which the Polish government and administration respond to rising problems and challenges - and the insufficiencies of it - constitute a relevant context condition according to some interviewed TSOs. In this respect, a representative of one of the organisations highlights, for instance, the unfriendly attitude of the current state authorities towards the third sector organisations, which generates a negative surrounding for their activities. Among the interviewed disability TSOs, it is the organisations in particular supporting caregivers that blame the Polish government for having deprived this group of people of social benefits. Moreover, according to a few TSOs in the (un)employment field, the recent changes in labour and social policy, including the resulting "flexibilisation" and "precarisation" of employment, have had a considerable impact on their work. Overall, however, it is interesting to note that many of the interviewed TSOs do not blame the state and its policy as the main cause of problems.

\section{TSOs' Responses to Changing Circumstances and New Challenges in Their Field of Action}

Our theoretical framework suggests that inappropriate or insufficient action by the state to realise its obligations towards vulnerable and excluded groups of people creates both a space and a trigger for civil society organisations to act and to adjust their solidarity approach. Our interviews provide us with in-depth insights to examine if and how the TSOs

October 2015, this point of view, together with a widespread narrative of citizens' protection, Polish sovereignty and an obligation to care for the Polish Catholic tradition, became hegemonic. This was the rationale for opposing the refugee relocation system in the EU, although some scholars (Pochyły 2017) claim that Polish foreign policy towards the refugee issue did not change that much between 2014 and 2016. 
under review responded to the changing circumstances and new demands in their fields of action.

Overall, it is striking that Polish TSOs applied three main strategies in order to cope with the new challenges and grievances, namely (1) the expansion of beneficiaries and activities, thus broadening the TSOs' scope of solidarity, (2) new alliance building with other organisations and (3) the establishment of new TSOs as a reaction to changed circumstances and resulting new needs. Interestingly, these strategies were not equally salient in each of the three fields of vulnerability. Instead, we can see field-specific approaches, with certain strategies having more weight in some fields and different strategies in others.

The broadening of the TSOs' scope of solidarity and action towards new target groups and the building of new alliances with other organisations were most prominently pursued by TSOs in the field of (un)employment. Trade unions, for instance, which used to provide activities and services primarily for "typical employees", have expanded their activities in order to address the needs of precarious workers, the working poor and working students. Our interviewees often emphasise that their understanding of "worker" is broader than the typical definition in the Polish labour code. For example, the term "workers" also includes persons who are employed on the basis of a civil law contract (so-called junk contracts in Poland), deprived of any working or social security rights. The respondents also highlight that their organisations respond to all the changes resulting from transformations in the labour market. Hence, they adopt a broad understanding of the term "employee" and help "everybody who has any relation to the labour market" (Unemp1 08/2016):

We answer to all the changes connected to flexibilisation and precarisation. For us 'employee' is each person who sells their labour. (Unemp3 09/2016)

This broad understanding was shared by unemployment TSOs. Their activities aim to help unemployed and poor people with diverse grievances and needs. In their work, they pay, for instance, "special attention to poor employees and poor people with disabilities, addicts and also homeless people" (Unemp7 10/2016). The interviewed unemployment 
TSOs also address various special groups of job seekers and the growing groups of people who are excluded from the labour market, such as the young unemployed, women, the disabled migrants and any others whose access to the labour market is more difficult:

Beneficiaries of our actions are all people who are in some way connected with the labour market, regardless of the professional statute or contract, whether they are employees or unemployed. (Unemp5 10/2016)

Moreover, working migrants have become an important addressee of the interviewed (un)employment TSOs. With the growing numbers of foreigners working in Poland, a number of the organisations under review - trade unions as well as other TSOs-have developed new strategies to integrate migrants into the Polish labour market. They aim to fight the unemployment of migrants, and if migrants are working, organisations guard their legal employment and advocate for equal labour rights.

In line with their broad understanding of target groups, many interviewed (un)employment TSOs have established alliances and different forms of cooperation with a varied range of other organisations, initiatives and movements. They support the work of other civil society organisations and public or private institutions working in the field of (un)employment, engage in the training of volunteers and cooperate with different social leaders and "social innovators" seeking to tackle unemployment:

We also support other NGOs, employees of other non-governmental organisations, employees of social enterprises, and employees of public institutions, labour offices, social assistance centres, all those who deal with or have contacts with the labour market somewhere. (Unemp2 08/2016)

Moreover, the broad range of cooperation partners and allies also includes movements of people threatened with eviction, women's movements for legal abortion, and movements against Comprehensive Economic and Trade Agreement (CETA), Transatlantic Trade and Investment Partnership (TTIP) and the extreme right and the rise of nationalism: 
We support tenant movements, participate in demonstrations, such as against CETA, criticise the extreme right, nationalism, and support feminist actions in the field of women's rights. (Unemp3 10/2016)

Interestingly, this broad approach towards target groups and alliance building is remarkably less influential in the disability field and is also less pronounced in the migration field, while the third strategy (new creation of TSOs) plays an important role in both fields (see below). As regards target groups and alliance building, TSOs in the field of disability have a more differentiated, particularistic understanding of their target groups, leading to a division of work between different types of disability TSOs rather than to cross-sectoral action and cooperation. For instance, some of the interviewed disability TSOs dedicate themselves to the problems of families of heavily disabled adults. Another organisation leads a day-care centre for people with intellectual impairments, while others focus on the rights of people with autism; still others devote their time to specific rare diseases, assist with the activation of the disabled or represent various problems of disabled children and adults. Similar to the division between special target groups, a segmented form of cooperation prevails among the interviewed disability TSOs. Usually, cooperation takes place between organisations with a similar profile and similar or even the same objectives. Hence, alliance building and solidarity are practised between groups that are very close to each other, but much less on a broader horizontal scale. Some interviewees suggest that, although they see the need of a broader solidarity approach, the situation forces them to focus on selected groups or a certain area. This deficit of solidarity between various groups is to some extent seen with regret:

Generally there is no solidarity between people; everybody is focused on their own issue. (Disab6 9/2017)

The segregation in the disability field is partly explained by the specificities of the various diseases and forms of disability. In part, the interviewed TSOs report a marked competition over (financial) resources and public and political attention between different groups of disabled and 
diseased people and their organisational representatives which further contributes to division in the field (e.g., Disab4 11/2016).

To a certain degree, the focus on specific target groups and needs is also true for TSOs in the migration field. Here, many TSOs have become established only recently and aim to fill a new gap that is still not sufficiently addressed by state policy. Facing new challenges, they centre their attention on those beneficiaries with the most pressing and urgent needs, which in the Polish case are primarily migrants from Ukraine. The fact that many Polish migration TSOs are in the early stages of development seems to contribute to their currently rather narrow focal point. However, this does not prevent them from opening their activities and services to migrants and refugees from other countries.

While the expansion of the scope of solidarity in terms of beneficiaries and related forms of action and alliance building emerged as an important response to recent challenges in the employment field, the establishment of new TSOs has been a relevant strategy in the fields of disability and migration in reaction to new circumstances and needs. In recent years, parts of the disability field have been shaped by restrictive state reforms. Our study shows that the withdrawal of the state from some of its obligations for disabled people and relatives who care for them has led to the creation of new disability, TSOs and the organisation of new volunteers and activists in social movements and civic initiatives. For instance, caregivers of adult disabled persons have been particularly affected by reductions in public support. In the face of changes in legislation and the resulting limitation in the level of social security for caregivers of the adult disabled, the members of that social group have begun to mobilise and organise themselves in new initiatives since 2012 and 2013 in order to fight for a return to the previous law, regain their social entitlements, generally improve their situation and fill the gaps in social security and support caused by this policy change:

I joined the organisation in 2013, after the government deprived us of social benefits. (Disab1 9/2016)

Organisation originated a bit later, but generally we started to act in 2013.

(Disab2 9/2016) 
The reason for establishing new initiatives was strictly bound to the unexpected change in the law at the end of 2012. Thus, there were no former initiatives or TSOs focused on that issue before 2012. The TSOs examined were oriented towards the articulation of the protest of certain groups and rapid changes in the law concerning support, so they did not seek broader contacts with other groups in the disability field with a different activity profile. Moreover, the people engaged with TSOs oriented on policy change concerning the benefits for caregivers had no or very few former contacts with other TSOs in the field of disability due to intensive daily engagement in caregiving.

In the migration field, new TSOs have been founded in recent years parallel to the arrival of many new migrants in Poland. Given that state policy in this area was still not sufficiently developed, civil society actors stepped in to mitigate the situation and to offer help to those in need. While other European countries have mostly been shaped by recent migration movements from the Middle East and North Africa, Poland has been most strongly affected by the arrival of hundreds of thousands of immigrants from Ukraine fleeing war and economic crisis. In response, new TSOs were created focusing primarily on migrants from Ukraine. Nevertheless, many of these TSOs do not exclusively provide support to Ukrainian migrants. Instead, they are open to assist other foreigners, too, such as people from the former Soviet Union (e.g., Belarusians, Russians and Chechens) or refugees from Syria or other countries hit by war and/ or crisis:

The main beneficiaries are Ukrainians living in Poland, but the organisation is not closed to immigrants from other countries. When publishing a newspaper, conducting trainings or meetings - we are always open; everyone has the right to come and it happens: Chechens, Poles from other organisations, Belarusians, Russians. (Migr3 09/2016)

In addition, a few other TSOs follow a broader approach and help any migrants, economic refugees, asylum seekers and/or citizens of countries facing war. In this respect, the interviewed TSOs underline, for instance: 
Our organisation aims to help everyone living or residing outside of their homeland ... we do not restrict ourselves to any group. (Migr4 09/2016)

We mainly focus on preventing social exclusion, and social exclusion can have many causes. [...] We fight stereotypes against foreigners. (Migr1 08/2016)

Only one interviewed organisation specifically provides direct charity help and services to Syrians in Syria-by providing humanitarian aid to local organisations:

In general, we provide this type of humanitarian aid to units that operate there, whether it is the Red Cross, local humanitarian units, so-called White Helmets, namely civil defence organisations and so on. (Migr8 10/2016)

\section{The Role of Transnational Solidarity in TSOs' Responses in Challenging Times of Crisis and Insufficient State Policy}

In addition to the three strategies of TSOs discussed in the previous section, our research reveals that for some TSOs searching for transnational solidarity is a further reaction to the encountered deficits of state policy, but also to the multiple crises in Europe and beyond. Among the TSOs that follow this path, the approach and degree of implementing transnational solidarity varies, however. Moreover, it is striking that for other interviewed TSOs the transnational aspect is almost absent or incidental. This applies particularly to the disability TSOs in our study.

For some of the organisations under review, engaging in transnational cooperation is a means of gaining access to inter- or transnational funding sources, mostly from European, Norwegian or Swiss funds:

We do not cooperate internationally, apart from financial support from the European Union. (Disab3 09/2016) 
Beyond these financial incentives, transnational partnerships and cooperation are also set up to exchange experience, information, knowledge (for instance, about innovative practices from abroad) and resources, and organise reciprocal support in various ways (including technical support). This applies to several of the interviewed TSOs in both unemployment and migration fields and to a few disability organisations:

For us, it is about the exchange of social capital and experiences, having someone in the place of action; if the people for whose rights we are fighting are in a country other than Poland. (Migr10 10/2016)

We cooperate, exchange experiences, support each other internationally. (Unemp5 10/2016)

Solidarity of all workers, regardless of industry, position, type of contract, gender, nationality and country. It is solidarity beyond borders, intercompany. It manifests itself in maintaining contacts with organisations in other countries to mobilise and support each other. (Unemp3 09/2016)

A part of the organisations belongs to European networks cooperating and implementing joint projects. For instance, Polish trade unions work side by side with other European trade unions (regional as well as federal) and engage in joint projects, analyses and support (demonstrations, funding, etc.). Moreover, transnational cooperation is used for joint lobbying, advocacy, networking and educational activities.

The first and probably most important step that leads us to real change in the migrants' and refugees' situation is raising awareness. (Migr9 09/2016)

There are also organisations that operate abroad, especially in countries affected by war and deep crises like in Ukraine or Syria. This is especially true in the field of migration, where several of the interviewed organisations operate transnationally because their work is related to problems on an international or global scale. However, not all of the migration TSOs in our study have intense, long-term cooperation with foreign organisations. Some of them, although conscious of existing problems set against 
an international or global backdrop, focus on activities in the local area. The most common activity is helping immigrants from different countries in Poland. When arriving in a new and foreign environment, migrants are often at a loss and need broad support that TSOs attempt to provide. Thus, helping in the local area seems relevant to the needs and the time and place, where they are reported:

We support migrants, foreigners, of different nationalities. It turns out that it is a large group of people, often vulnerable, when they need support, not to get lost, to start to function normally. (Migr5 09/2016)

As was aforementioned, even if the purpose of most organisations is to help particular groups (like Ukrainians in Poland), they are also open to Ukrainians in difficult situations living in Ukraine. Organisations that support a specific national group in Poland often start to expand their activity abroad because of the links of their beneficiaries to their places of origin. They create networks of migrants in Poland with their families and friends abroad:

Our foundation participates in actions like fundraising or collection of medicines for people in a difficult situation in the East, especially for orphaned children because of the war. There are grassroots initiatives of our beneficiaries which we also join. (Migr7 10/2016)

Compared to the enhanced attention on Eastern Europe, Polish migration TSOs are considerably less dedicated to refugees and people in need from the Middle East and have barely established transnational linkages with that region. In fact, only one organisation we interviewed specifically provides direct charity help and services to Syrians in Syria.

While some interviewed TSOs underline that they use transnational cooperation and solidarity as a means to enhance their opportunities and impact and to cope with restrictive circumstances, other TSOs rather emphasise the barriers to transnational cooperation. Such barriers are seen in the scarcity of resources, such as funds, time and staffing in the organisations and its skillset (for instance, in reference to language and communication). 
Barriers of language. For example, I don't know any (except Silesian), so for me there is a barrier of language. (Disab2 9/2016)

Language. And the finances on our side. (Disab1 9/2016)

Some organisations also point to the difference in goals and problems between themselves and organisations abroad. However, even those who report no transnational cooperation share the opinion that such contact could be useful and would not discount it in the future.

I think that there would be some profit, because we could exchange experiences with each other. We could get some inspiration. (Disab6 9/2016)

Only in exceptional cases is transnational solidarity not regarded as something desirable. One disability TSO states that their concern is focused on a very local or national scale, and there is no interest in more complex and stable cooperation with foreign organisations. Generally, the least commitment to such transnational relations can be found among policy-oriented disability organisations that struggle for more decent social security for caregivers. This finding is astonishing because there are transnational initiatives that integrate many national social movements, regarding long-term care and family caregivers, such as Eurocarers. It is interesting that reference to Eurocarers did not occur in any of the interviews.

\section{Conclusions}

Our study has provided instructive evidence on how Polish transnational solidarity organisations have mobilised and organised collective action in order to fill the gap provoked by the growing divide between increasing and new grievances and needs in times of recent economic, social and migration challenges, on the one hand, and insufficient and inadequate state polices, on the other. As our analysis shows, the TSOs under review have done so by applying various strategies with differing weight and relevance across the three analysed fields of vulnerability. Across the fields 
of unemployment, migration and disability, we see that these organisational strategies have been considerably shaped by the fact that TSOs adapted to changed circumstances and found new ways to show solidarity with vulnerable groups. These are similar to the findings of existing social movement studies (Diani 2019; Gumbrell-McCormick 2011; Kirton and Greene 2002; Wibberley et al. 2018; Marino et al. 2015), where the labour- and unemployment-related TSOs, in particular, expanded their scope of solidarity towards new target groups and problems which traditionally were not regarded as labour rights or unemployment issues. Among others, Polish unions, and other labour as well as unemployment organisations, have broadened their range of activities in order to target, for instance, precarious atypical workers, jobless women, young people, migrants or other disadvantaged, deprived and excluded groups. Moreover, Polish (un)employment TSOs have also broadened their focus of activity by engaging in new alliances with other organisations from various neighbouring - and partly overlapping-issue fields, dealing, for instance, with problems of eviction, women's rights, rising nationalism or international neoliberal agreements such as CETA and TTIP. In comparison, TSOs in the fields of disability and migration have been characterised by the fact that many of them were created in recent years in response to newly arising grievances and needs and against the backdrop of insufficient state support. In the field of disability, TSOs representing the needs of caregivers are a particularly salient example of this development (Kubicki 2016; Bakalarczyk 2015). Moreover, in the field of migration, it was most striking that many TSOs have recently been established as a reaction to the influx of many migrants fleeing from war and economic crisis in Ukraine.

In addition, it emerged from our study that some TSOs have adapted to new circumstances by creating new or by intensifying existing transnational solidarity interlinkages. Among the analysed TSOs, the group of (un)employment organisations has the strongest transnational bonds, both by cooperating with other countries' organisations and by helping excluded people abroad, namely the unemployed in Spain or Greece. Furthermore, some migration organisations send aid abroad to countries facing war and other types of conflicts. However, their primary focus of activity is on migrants, refugees and asylum seekers who have already 
arrived in Poland (especially Ukrainians, but not exclusively). In contrast, disability organisations are the ones that make the least use of transnational cooperation and action. Instead, each of them centres on a very specific slice of reality: different groups of disabled or diseased people and their caregivers. They mostly answer to the rather particular needs of the various groups almost abandoned by the Polish state.

Interestingly, only a part of the interviewed TSOs explicitly discussed the reasons and circumstances of the (new) needs and demands they aim to cope with. The other part appears to be mainly help- and serviceoriented and tends to avoid addressing the economic or political circumstances of their work. In fact, most TSOs across the three fields aim to tackle the direct problems and meet the immediate demands arising in their field of activity. While TSOs in other European countries regard the multiple crises of the past decade as a relevant factor of their work, this does not apply to most of the Polish TSOs under review. In this sense, Polish solidarity work is not driven by the socio-economic crisis and the so-called refugee crisis affecting the EU at large but is rather a reaction to grievances and conflicts associated with public policies and measures adopted by the Polish government in the different fields of activities.

Nevertheless, some TSOs underlined the indirect impact of the economic crisis and/or the immediate relevance of domestic state policies on their target groups and their own activities and agendas. In the disability field, for example, social cuts in benefits for caregivers of disabled people were mainly explained by the difficult situation of public finances (Ministry of Labour and Social Policy 2012). The unsatisfactory commitment of the state and public institutions was one of the perceived causes of solidary activity of many organisations in that field. This observation is true not only for those who started their activity in 2013 as a response to the cuts on social benefits but also to older organisations, for instance, TSOs representing people with rare diseases, who could not receive appropriate treatment and therapy in the mainstream public health sector. Interestingly, the influence of the larger economic crisis on these restrictive domestic policy changes was not addressed by our interviewees in this context.

As regards the (un)employment field, TSOs are notably affected by the recent changes in the labour market and related labour market policy that 
go along with a "precarisation" and "flexibilisation" of employment conditions and a loss in the level of social security. However, against the backdrop of complex and variously interwoven contextual factors, it is often not easy to distinguish the role of more general and international developments, like the economic and financial crisis, insufficient or inadequate state responses and specific national policies. In fact, labourconnected TSOs, for instance, see their work as a broader process of answering the challenges of our time: growing liberalisation and deregulation of the labour market, as well as the decreasing role of trade unions and other organisations representing working people. In part, their activity is justified by the lack of sufficient state labour policy, but also by the need to strengthen the employees' side and that of the middle class in times of globalisation.

Finally, TSOs working in the field of migration stated that their solidarity activities resulted from the mass migration of people from eastern areas (mainly from Ukraine) and, to a smaller degree, the larger migration crisis in and beyond Europe. The absence of an adequate response by the Polish government is perceived only sometimes as an impact factor on their work. In their view, they mostly respond to the immediate needs of migrants and victims of conflict in other countries, rather than to consequences of state policy, which seem less evident for civil society actors in this field than to those of the other two.

\section{References}

Ancelovici, M., Dufour, P., \& Nez, H. (Eds.). (2016). Street Politics in the Age of Austerity: From Indignados to Occupy. Amsterdam: Amsterdam University Press. Bakalarczyk, R., Polakowski, M., Kubicki, P., \& Szelewa, D. (2015). Niepetnosprawnośc: problemy opieki. Warszawa: Friedrich-Ebert-Stiftung.

Cabot, H. (2018). The European Refugee Crisis and Humanitarian Citizenship in Greece. Journal of Anthropology, 84(5), 747-771.

Chrysostomou, A. (2015). When the State Fails: The Rise of Informal Civil Society Organisations in Greece. Lund: Department of Political Science. Retrieved from: http://lup.lub.lu.se/luur/download?func=downloadFile\&recordOI $\mathrm{d}=5425978 \&$ \&fileOId $=5425983$ 
della Porta, D. (2015). Social Movements in Times of Austerity: Bringing Capitalism Back into Protest Analysis. Cambridge: Polity Press.

Diani, M. (2019). Unions as Social Movements or Unions in Social Movements? In J. R. Grote \& C. Wagemann (Eds.), Social Movements and Organized Labour, Passions and Interests (pp. 43-65). London: Routledge.

Eurostat. (2017). First Instance Decisions on Applications by Citizenship, Age and Sex Annual Aggregated Data (Rounded). Retrieved from: http://appsso.eurostat.ec.europa.eu/nui/show.do?dataset=migr_asydcfsta\&lang=en

Giugni, M., \& Grasso, M. (2016). How Civil Society Actors Responded to the Economic Crisis: The Interaction of Material Deprivation and Perceptions of Political Opportunity Structures. Politics and Policy, 44, 447-472.

Grasso, M., Yoxon, B., Karampampas, S., \& Temple, L. (2019). Relative Deprivation and Inequalities in Social and Political Activism. Acta Politica, 54, 398-429.

Gumbrell-McCormick, R. (2011). European Trade Unions and "Atypical" Workers. Industrial Relations Journal, 42(3), 293-310.

Kirton G., Greene A. (2002). The dynamics of positive action in UK trade unions: the case of women and black members, Industrial relations journal, Vol 33, issue 2, June 2002 pp. 157-173.

Kirton, G., \& Greene, A. M. (2005). Gender, Equality and Industrial Relations in the 'New Europe': An Introduction. European Journal of Industrial Relations, 11(2), 141-149.

Kubicki, P. (2016). Środowiska osób z niepetnosprawnościami wobec polityki publicznej-studia przypadków. Warszawa: Studia z polityki publicznej.

Marino, S., Penninx, R., \& Roosblad, J. (2015). Trade Union, Immigration and Immigrants in Europe Revisited: Unions' Attitudes and Actions Under New Conditions. Comparative Migration Studies, 3(1), 1-16.

Milner, S., \& Mathers, A. (2013). Membership. Influence and Voice: A Discussion of Trade Union Renewal in the French Context. Industrial Relations Journal, 44(2), 122-138.

Ministry of Family, Labour and Social Policy. (2017). Program kompleksowego wsparcia dla rodzin "Za życiem". Warszawa. Retrieved from: http://www.zazyciem.mrpips.gov.pl/program-za-zyciem

Ministry of Labour and Social Policy. (2012). Projekt z dnia 26 lipca 2012 r. ustawy o zmianie ustawy o świadczeniach rodzinnych oraz niektórych innych ustaw. Retrieved from: http://www.sejm.gov.pl/Sejm7.nsf/PrzebiegProc. xsp?nr=724 
Mohan, S. (2002). Role and Relevance of Civil Society Organisations. The Indian Journal of Political Science, 63(2/3), 193-211.

Narkiewicz, K. (2017). Goście czy najeźdźcy? Edukacyjne aspekty debaty publicznej na temat przyjęcia uchodźców w Polsce. Dyskursy Mtodych Andragogów, $18,103-116$.

Petelczyc, J. (2017). Polityka społeczna wobec obywateli - wybrane reformy rynku pracy i zabezpieczenia społecznego w czasie kryzysu gospodarczego. In M. Theiss, A. Kurowska, J. Petelczyc, \& B. Lewenstein (Eds.), Obywatel na zielonej wyspie, polityka spoteczna i obywatelstwo spoteczne $w$ Polsce $w$ dobie europejskiego kryzys ekonomicznego (pp. 35-70). Warsaw: IFiS PAN.

Pochyły, P. Refugees/Migrants and Border Security in the Annual Address of Poland's Foreign Ministers in the Years 2014-2016. Przeglad Politologiczny, 2017, 2017(3), 89-103.

Rae, G. (2012). Austerity Policies in Europe: The Case of Poland. Berlin: Friedrich Ebert Stiftung, International Policy Analysis.

Rymsza, M. (2006). Polityka społeczna a więzi społeczne. Przypadek III Rzeczpospolitej. Societas/Communitas, 1, 197-220.

Sotiropoulos, D., \& Bourikos, D. (2014). Economic Crisis, Social Solidarity and the Voluntary Sector in Greece. Journal of Power, Politics and Governance, 2(2), 33-53.

Szczupak, K., Theiss, M., \& Petelczyc, J. (2018). Poland, Integrated Report on Transnational Solidarity in the Public Domain (WP5). Retrieved from: https://transsol.eu/files/2018/05/deliverable-5-1.pdf

Theiss, M., Kurowska, A., Petelczyc, J., \& Lewenstein, B. (2017). Obywatel na zielonej wyspie. Polityka spoteczna i obywatelstwo spoteczne $w$ Polsce $w$ dobie europejskiego kryzysu ekonomicznego (pp. 221-236). Warsaw: IFiS PAN.

TransSOL. (2016). Work Package 2 Integrated Report on Reflective Forms of Transnational Solidarity. Retrieved from: https://blogs.uni-siegen.de/transsol/files/2016/12/Integrated-Report-on-Reflective-Forms-of-TransnationalSolidarity.pdf

Urząd do Spraw Cudzoziemców (2018). https://udsc.gov.pl/statystyki/

Wibberley, G., Bennet, T., Jones, C., \& Hollinrake, A. (2018). The Role of Trade Unions in Supporting Victims of Domestic Violence in the Workplace. Industrial Relations Journal, 49(1), 69-85. 
Open Access This chapter is licensed under the terms of the Creative Commons Attribution 4.0 International License (http://creativecommons.org/licenses/ by/4.0/), which permits use, sharing, adaptation, distribution and reproduction in any medium or format, as long as you give appropriate credit to the original author(s) and the source, provide a link to the Creative Commons licence and indicate if changes were made.

The images or other third party material in this chapter are included in the chapter's Creative Commons licence, unless indicated otherwise in a credit line to the material. If material is not included in the chapter's Creative Commons licence and your intended use is not permitted by statutory regulation or exceeds the permitted use, you will need to obtain permission directly from the copyright holder.

(c) $\underset{8 \mathrm{BY}}{(1)}$ 